\title{
Racionalidade e gerencialismo na política educacional paulista de 1995 a 2014: muito além das conjunturas
}

Géssica Priscila Ramos a

\section{Resumo}

Este artigo objetiva apresentar o modelo de gestão que embasa a política educacional paulista de 1995 a 2014, reconstruindo, para tanto, a lógica que sustenta e entrelaça os principais programas, projetos e ações implementados no período. A partir de análise bibliográfica e documental, verificou-se que, nesse período, os eixos racionalização organizacional, mudança nos padrões de gestão e melhoria na qualidade do ensino, mantiveram-se como base da reforma educacional no Estado. Sob essa configuração, o material analisado revela que tal processo sustenta-se num modelo gerencialista e de racionamento da educação e, por conseguinte, da própria qualidade do ensino.

Palavras-chave: Política educacional paulista. Gestão educacional. Qualidade de ensino.

\section{Introdução}

O objetivo deste artigo é apresentar o modelo de gestão que embasa a política educacional paulista de 1995 a 2014, reconstruindo, para tanto, a lógica de racionalidade e gerencialismo que sustenta e entrelaça os principais programas, projetos e ações implementados no período. O pressuposto é que a gestão é um processo histórico, resultante de um contexto social, econômico, político, etc. Como lembram Ribeiro e Chaves (2012, p. 1), a gestão, portanto, reveste-se de contradições e interesses diversos, não sendo, portanto, neutra, nem abstrata, tampouco "generalista ou com finalidade em si mesma". Ao contrário, ela se articula ao "desenvolvimento do sistema econômico, das políticas do Estado, no qual está inserida e reflete os posicionamentos dos gestores que a assumem"

a Universidade Federal de São Carlos - UFSCar, Departamento de Educação. São Carlos, São Paulo, Brasil. 
(idem). Assim, entender a educação, num dado contexto histórico, implica que se busque conhecer o modelo que a embasa em sua organicidade, para além de se reconhecer seus fenômenos de conjuntura, tendo em vista que:

Também os fenômenos de conjuntura dependem, é claro, de movimentos orgânicos, mas seu significado não tem um amplo alcance histórico: eles dão lugar a uma crítica política miúda, do dia-a-dia, que investe os pequenos grupos dirigentes e as personalidades imediatamente responsáveis pelo poder. Os fenômenos orgânicos dão margem à crítica histórico-social, que investe os grandes agrupamentos, acima das pessoas imediatamente responsáveis e acima do pessoal dirigente (GRAMSCI, 1968, p. 45-6).

Para tanto, este artigo utiliza como recurso de pesquisa a análise bibliográfica e documental sobre a política educacional estudada, objetivando reconstruí-la em sua organicidade. Tal como num quebra-cabeça, o que se faz é o resgate dos programas, projetos e ações paulistas centrais do período, situando-os para além de seus contextos conjunturais, em sua estrutura orgânica e histórica, dando-lhes o significado que os sustentam no modelo de gestão estudado.

Destarte, este artigo analisa o modelo de gestão do Estado de São Paulo, sinalizando que, não obstante as diferentes administrações e enfoques políticos, isto é, seus elementos de conjuntura, "que se apresentam como ocasionais, imediatos, quase acidentais", segundo Gramsci (1968, p. 45), estes não foram suficientes para caracterizar alterações profundas na estrutura da política oficial paulista consolidada entre os anos de 1995 a 2014.

\section{Racionalidade e gerencialismo como elementos da estrutura orgânica}

Sob a genérica denominação "Nova Gestão Pública"1, o modelo gerencialista de gestão objetiva agregar princípios, valores e estratégias provenientes da administração privada (racionalização de tarefas; separação entre os níveis estratégico e operacional de decisão e ação; gestão por objetivos/resultados; remuneração por desempenho, etc.) à gestão pública. Apesar de ser um modelo de gestão, segundo Terto e Pereira (2011, p. 3), ela alia a seu histórico uma "produção intelectual comprometida com a criação de um programa baseado nas

Segundo Junquilho (2010), o termo Nova Gestão Pública, no Brasil, traduz a expressão inglesa New Public Management, que, na literatura internacional, abarca as reformas do Estado realizadas a partir dos anos de 1970, baseadas na corrente gerencialista do pensamento administrativo. 
ideias do livre mercado e em consonância com a ideologia neoliberal", o que faz com que seus usos e finalidades transcendam seu argumento de melhoria da eficiência no uso dos recursos públicos.

Assim, segundo Costa (2010, p. 153-4), é o pressuposto da racionalidade econômica que define, nesse modelo, as expectativas de comportamento dos agentes públicos, impregnando as ideias de Estado, de governo e de administração pública com valores da "livre-iniciativa e do mercado na produção [...], com todas as consequências práticas, teóricas e ideológicas dessa opção". Com isso, há uma tendência para o enxugamento da atuação do Estado notadamente no campo social, tendo como características básicas desse processo a criação de políticas, que caminham no sentido da descentralização (usualmente tutelada) de suas atribuições, para a sociedade em geral ou para setores específicos dela.

No Brasil, esse modelo, fortalecido no cenário mundial notadamente a partir dos anos 1980, e com características presentes no país desde os governos militares, foi claramente adotado por volta dos anos 1990, com Fernando Collor de Mello, do PRN (Partido da Reconstrução Nacional) - primeiro Presidente brasileiro eleito por voto direto após o regime militar. Contudo, consolidou-se apenas por meio do Plano Diretor da Reforma do Aparelho do Estado (BRASIL, 1995), sob a denominação Administração Pública Gerencial posta por Bresser-Pereira, responsável pelo Ministério da Administração Federal e da Reforma do Estado (JUNQUILHO, 2010), durante o governo Fernando Henrique Cardoso, quando se explicitam os pressupostos e mecanismos para implementação de uma reforma de cunho gerencial.

Assim, por meio desse Plano Diretor, o que se pretendia, no Brasil, era mudar "o modo de gestão e o relacionamento da União com Estados, com municípios e a vinculação da Administração com a sociedade", a partir de um processo de reforma do Estado e de seu aparelho (BRASIL, 2002, v.2, p. 280-1), instalando no país uma administração pública de cunho gerencial, sob a justificativa de se corrigir falhas cumulativas das gestões anteriores. O pressuposto era de que a crise que o país havia passado na década precedente era resultado de uma crise do próprio Estado brasileiro que havia se desviado "de suas funções básicas para ampliar sua presença no setor produtivo", ocasionando uma "gradual deterioração dos serviços públicos" e "o agravamento da crise fiscal e, por consequência, da inflação" (BRASIL, 1995, p. 1).

Desse modo, o documento Plano Diretor da Reforma do Aparelho do Estado traçou como estratégias básicas para a Reforma: a) a reorganização das estruturas administrativas do Estado em "bases modernas e racionais", "com ênfase na qualidade e na produtividade do serviço público" e em uma "verdadeira 
profissionalização do servidor" (BRASIL, 1995, p. 1); b) a redução do papel do Estado como executor ou prestador direto de serviços e provedor dos serviços, notadamente dos serviços sociais. Nesse modelo, o Estado continuaria a subsidiar serviços em termos de regulação e coordenação, mas buscaria também "o controle social direto e a participação da sociedade" e a "progressiva descentralização vertical, para os níveis estadual e municipal, das funções executivas no campo da prestação de serviços sociais e de infraestrutura" (idem, p. 5).

Ainda que o Ministério da Educação (MEC) não tenha sido destacado como um dos ministérios formuladores desse Plano, enquanto ministério setorial, ele teve papel de parceiro na formulação e na implantação de seus projetos, tendo em vista que a Reforma deveria acontecer "nas diversas unidades organizacionais de cada segmento da administração pública brasileira" (BRASIL, 1995, p. 41). Além disso, segundo o Plano, o setor educacional era essencial para essa Reforma, na medida em que atuaria no desenvolvimento (pelo investimento em capital humano), na democracia (pela promoção dos cidadãos) e na distribuição de renda mais justa ("dada a oferta muito superior à demanda de mão de obra não especializada") (idem, p. 5). Destarte, no campo da educação, essa nova gestão pública, ao se pautar sob o racionamento e o gerencialismo, acabou tendo como estratégias básicas a descentralização de tarefas com a ampliação da autonomia operacional das instituições, associada à potencialização das avaliações nacionais de educação, da meritocracia e da responsabilização dos docentes e gestores pelos resultados obtidos, segundo as metas definidas externamente.

Enquanto esse modelo se instalava e se difundia dentro da administração pública federal, o que se observa é que ele também era adotado por várias gestões estaduais ou expandido, como no caso de São Paulo. No Estado paulista, os três primeiros governos democráticos paulistas posteriores ao Regime Militar (Franco Montoro, Orestes Quércia e Luiz Antônio Fleury Filho), todos do PMDB (Partido do Movimento Democrático Brasileiro), já esboçavam ações fundadas nesse modelo². Tal fato, explica-se na medida em que "o PMDB sempre manteve laços com a classe dominante", expressando tão somente uma oposição ao regime militar autoritário, mas não ao capital (MARSIGLIA, 2011, p. 103).

Entretanto, tal modelo efetivamente se definiu como padrão em São Paulo a partir de 1995, mas sob a égide do PSDB (Partido da Social Democracia Brasileira). Desse modo, para além de uma afinidade partidária, o governador paulista de meados dos anos 1990, Mario Covas, manteve com os governos de "Fernando

\footnotetext{
Segundo Martins (2010, p. 19), dentro dessa configuração de gestão, especialmente Quércia e Fleury criaram programas educacionais que possibilitaram a entrada de "mecanismos da iniciativa privada no interior das redes municipais de ensino, respaldadas por um suposto diagnóstico educacional precário".
} 
Henrique Cardoso uma ampla concordância ideológica e administrativa, objetivando inserir São Paulo num lugar de destaque no país", dentro do citado processo de Reforma (RAMOS, 2012, p. 130-1). Assim, no campo educacional, a gestão Covas (SÃO PAULO, 1995) estabeleceu como diretriz de sua atuação a "revolução na produtividade dos recursos públicos", tendo por base os eixos: racionalização organizacional, mudança nos padrões de gestão e melhoria na qualidade do ensino (NEUBAUER, 1999).

Segundo o Comunicado de 22 de março de 1995 da Secretaria da Educação do Estado de São Paulo - SEE (SÃO PAULO, 1995), a qualidade do ensino, um dos eixos dessa reforma, viria como resultado de uma "revolução na produtividade dos recursos públicos", desencadeada pela "revisão do papel do Estado na área de prestação de serviços educacionais", no sentido de transformá-lo num agente formulador da política educacional paulista, "responsável pelo papel de planejador estratégico e não o de simples prestador de serviços". Por tal razão, conforme o referido Comunicado (idem), essa revisão do papel do Estado deveria se nortear por duas diretrizes básicas, ou melhor, pelos outros dois eixos centrais da reforma educacional: a racionalização organizacional e as mudanças nos padrões de gestão. A racionalização organizacional teria como foco "construir na Secretaria uma máquina administrativa leve, ágil, flexível, eficiente e moderna, capaz de ser um instrumento eficaz na implantação de uma nova política educacional", o que implicaria no alcance de dois objetivos básicos: 1) a implantação de um sistema eficaz de informatização dos dados educacionais; 2) a desconcentração e descentralização de recursos e competências por meio da reorganização da estrutura da Secretaria de Educação e do estabelecimento de parcerias para prestação dos serviços educacionais (idem). No caso da mudança nos padrões de gestão, ela teria como metas: 1) a racionalização do fluxo escolar, revertendo o quadro de repetência e evasão nas escolas estaduais paulistas; 2) a instituição de mecanismos de avaliação dos resultados; 3) o aumento da autonomia administrativa, financeira e pedagógica das escolas (idem). Foi com esses contornos que se desenvolveu a gestão educacional paulista do período estudado, não obstante suas mudanças conjunturais de governos, políticas e programas educacionais.

\section{Governos, políticas e programas como elementos de conjuntura}

Desde 1995, vêm se revezando, no governo do Estado de São Paulo, lideranças do PSDB. Desse modo, alternaram-se no governo do Estado nomes como Mário Covas (1995-1998; 1999-01/2001), Geraldo Alckmin (02/2001-2002; 2003-2006; 2011-atual), José Serra (2007-03/2010) e Alberto Goldman (04/2010-12/2010). Na pasta da educação, paralelamente, circularam figuras como Teresa Roserly Neubauer da Silva (1995-03/2002), Gabriel Benedito Issaac Chalita 
(04/2002-04/2006), Maria Lucia Marcondes Carvalho Vasconcelos (04/2006-2007), Maria Helena Guimarães de Castro (07/2007-2009), Paulo Renato Costa Souza (04/2010-01/2011) e Herman Jacobus Cornelis Voorwald (02/2011-2015).

Tal período, portanto, teve início em 1995 com a eleição de Mário Covas para o governo estadual. Ele completou seu primeiro mandato em 1998, mas foi reeleito nesse mesmo ano. Covas ficou no governo do Estado até janeiro de 2001, quando, por motivos de saúde, veio a falecer. Durante seus quase dois mandatos completos, esteve no papel de secretária da educação Rose Neubauer, voltando-se para a construção daquilo que chamou de 'A escola de cara nova' (SÃO PAULO, 1997). Destarte, podem ser destacadas dentre as principais ações de Neubauer na pasta da educação: a extinção do Programa Escola Padrão, criado pelo governo de Luiz Antônio Fleury Filho; a extinção das Divisões Regionais de Ensino e criação das Diretorias Regionais de Ensino; a criação do Programa Escola em Parceria; a organização do Ensino Fundamental em dois ciclos; a instituição do Regime de Progressão Continuada no Ensino Fundamental; a criação da política de Reorganização da Rede Física; a criação das Classes de Aceleração; a implantação do Programa de Ação de Parceria Educacional Estado-Município (municipalização do ensino); a criação do Sistema de Avaliação do Rendimento Escolar do Estado de São Paulo (SARESP); a criação do Programa de Educação Continuada (PEC) e do Programa de Educação Continuada-Universitário (PEC-Universitário); a informatização da rede administrativa da educação, entre outras.

Em meados de janeiro de 2001, com o falecimento do governador Mário Covas, Geraldo Alckmin, seu vice, assumiu o cargo, mantendo Rose Neubauer na Secretaria da Educação. Esta permaneceu na Secretaria até março de 2002, quando, por questões pessoais, pediu demissão. Com sua saída, o final dessa gestão governamental contou com Gabriel Chalita como novo secretário da educação. Sua gestão, nesse momento, acabou caracterizando-se basicamente pela manutenção das políticas e diretrizes definidas durante a gestão Neubauer.

Com a reeleição de Geraldo Alckmin como governador do Estado em 2003, Chalita manteve-se como secretário da educação. Dando continuidade à sua prática administrativa anterior, este conservou as políticas iniciadas na administração de Neubauer. Todavia, Chalita acabou se destacando também por algumas políticas próprias, como aquelas voltadas para a capacitação do magistério (Programa Letra e Vida, Programas Teia do Saber e Rede do Saber, Bolsa Mestrado, entre outras) e para inclusão social por intermédio da escola (Programa Escola de Tempo Integral, Programa Escola da Família, entre outras), fortalecendo o slogan de "Governo Educador, Solidário e Empreendedor" impresso por Alckmin em sua gestão (SÃO PAULO, 2003, p. 2). 
Alckmin ficou no governo até março de 2006, quando se retirou do cargo para concorrer às eleições presidenciais do período. Com isso, Cláudio Lembo, seu vice-governador, assumiu o final da gestão e, com ele, passou a atuar na pasta da educação Maria Lucia Marcondes Carvalho Vasconcelos, que, em ritmo de final de mandato, acabou basicamente dando continuidade aos programas em educação criados ou mantidos durante o governo Alckmin.

Em 2006, novas eleições ocorreram e José Serra saiu vitorioso no Estado, assumindo o cargo de governador. Em sua gestão, três secretários se revezaram na pasta da educação, sendo: Maria Lucia Marcondes Carvalho Vasconcelos, Maria Helena Guimarães de Castro e Paulo Renato Costa Souza.

Maria Lucia Vasconcelos ficou no cargo até junho de 2007. Logo de início, lançou um novo programa estadual de educação chamado: 'Uma nova agenda para educação pública', que estipulava o cumprimento de 10 metas até 2010 , dentre elas: reduzir $50 \%$ das taxas de reprovação da $8^{\mathrm{a}}$ série e do Ensino Médio; fazer programas de recuperação nos ciclos finais; melhorar em $10 \%$ as notas em avaliações nacionais e estaduais; atender $100 \%$ dos jovens e adultos do Ensino Médio com currículo profissionalizante; utilizar a estrutura de tecnologia da informação e da Rede do Saber para programas de formação continuada de professores na própria escola; descentralizar e/ou municipalizar o programa de alimentação escolar (SÃO PAULO, 2007). Com isso, reforçava-se a ideia de construção de um modelo de escola reinventada e pautada pela qualidade (ESTADO DE SÃO PAULO, 2007).

Posteriormente, foi Maria Helena Guimarães de Castro quem assumiu a Secretaria da Educação, seguindo as mesmas diretrizes traçadas. Maria Helena, por sua vez, ficou no cargo até o final de 2009 e conseguiu concentrar em sua gestão a maior parte das principais políticas educacionais criadas durante o governo Serra, como: a vinculação da política de bonificação à avaliação do desempenho do magistério e da escola; a implantação do Programa de Valorização pelo Mérito; a aprovação da nova proposta curricular para o Ensino Fundamental e Médio; a redefinição das matrizes de referência do SARESP; a criação dos programas Ler e Escrever, São Paulo faz Escola e Recuperação da Aprendizagem; a instituição do Programa de Qualidade da Escola (PQE) e do Índice de Desenvolvimento da Educação do Estado de São Paulo (IDESP).

Paulo Renato Costa Souza assumiu a educação paulista logo no início de 2010, com a saída de Maria Helena de Castro da Secretaria. Nesse mesmo ano, ainda em março de 2010, o governador Serra se retirou do governo do Estado para 
concorrer às eleições presidenciais, assumindo o governo seu vice, Alberto Goldman, que manteve Paulo Renato como secretário da educação até o final do mandato. Nesse curto período, Paulo Renato conseguiu lançar ações bastante impactantes no setor com a criação do Programa + Qualidade na Escola, que envolveu, dentre outras coisas: a criação da Escola de Formação de Professores do Estado de São Paulo; as alterações no modelo de ingresso dos profissionais do magistério, com a introdução de curso de formação após o processo seletivo; e a criação de uma avaliação para os professores temporários como parte dos requisitos na escolha de aulas.

No final de 2010, Geraldo Alckmin novamente foi eleito como governador no Estado de São Paulo. Com ele, atuou na secretaria da educação Herman Jacobus Cornelis Voorwald. A partir de então, tentou-se imprimir no Estado a ideia de educação como compromisso central da referida gestão, pelo Programa Educação-Compromisso de São Paulo (SÃO PAULO, 2011). Assim, além da manutenção da política educacional em vigência, esse governo teve ações significativas nesse campo. Destacam-se nesse sentido: a reestruturação da Secretaria da Educação; a reestruturação da carreira do magistério; a reformulação do programa de Valorização pelo Mérito; a implantação de uma nova divisão do Ensino Fundamental em três ciclos (do $1^{\circ}$ ao $3^{\circ}$ ano, do $4^{\circ}$ ao $6^{\circ}$ ano e do $7^{\circ}$ ao $9^{\circ}$ ano); entre outras. Apesar desse histórico e de suas nuanças administrativas, o Estado de São Paulo conseguiu manter, desde 1995, coerência ideológica e sequência gerencial, sobretudo no campo da educação, como se verá adiante.

\section{A racionalização organizacional como princípio da mudança no padrão de gestão}

A gestão, dentro do modelo gerencial, tem entre suas características básicas, segundo Bresser Pereira (1996), o estabelecimento de processos de descentralização pautados na transferência de recursos e atribuições (para os níveis políticos regionais e locais) e de tarefas administrativas (entre administradores públicos), bem como no estabelecimento de organizações com poucos níveis hierárquicos. Souza Filho (2009, p. 6-7) interpreta que a estratégia é viabilizar o ajuste fiscal e a mudança institucional da administração pública, por meio da redução do aparelho do Estado (com práticas de terceirização, privatização, extinção de órgãos e focalização de gastos sociais) e centralizar e fortalecer os núcleos de decisão e controle das políticas.

Dessa forma, o eixo mudança no padrão de gestão, consolidado pela reforma educacional iniciada no Estado de São Paulo a partir de 1995, apresenta clara e 
fortemente a presença do princípio da racionalização organizacional e dos gastos com o setor, segundo o modelo gerencialista assumido, tendo em vista, ao mesmo tempo, a redução do tamanho do Estado e sua manutenção no controle e poder decisório. As ações, nesse caso, agiram basicamente em três aspectos principais: a) no enxugamento da estrutura organizacional da SEE e da rede de ensino, com a implantação de um modelo de descentralização do âmbito operacional, b) na redefinição de um novo modelo de controle de gestão, pela prática da tutela da descentralização, c) na redefinição das relações entre os poderes públicos, entre o poder público e a sociedade, entre a Secretaria e as escolas e entre a sociedade e a escola, na tentativa de configuração de um novo pacto social, em que o Estado assumisse claramente papel regulador e avaliador e a sociedade, papel operativo e fiscalizador.

Sobre o aspecto do enxugamento da estrutura organizacional da SEE e da rede de ensino, bem como da implantação de um modelo de descentralização do âmbito operacional da educação paulista, observa-se que foi a partir de 1995 que a Secretaria começou a implantar uma série de medidas no setor, dentro da perspectiva de sua racionalização organizacional e de gastos. Uma de suas primeiras ações nesse sentido foi a extinção das Divisões Regionais de Ensino (NEUBAUER, 1999). Com essa medida, a estrutura e atribuições dos órgãos e competências das autoridades previstas para as Divisões Regionais de Ensino e Divisão Especial de Ensino de Registro (ambas instâncias intermediárias entre os órgãos centrais e as Delegacias de Ensino) foram reorganizadas. Assim, a Delegacia de Ensino (que em 1999, passou a se chamar Diretoria de Ensino ou Diretoria Regional de Ensino) ficou diretamente subordinada à Coordenadoria de Ensino do Estado. Essas ações agiram no enxugamento da estrutura organizacional da SEE, ao atuarem: na extinção dos órgãos centralizados e no repasse de recursos humanos e materiais para instâncias descentralizadas do sistema, para que tivessem alguma autonomia financeira e administrativa, sobretudo, para buscar parcerias para prestação dos serviços educacionais; na finalização da duplicidade na execução das tarefas e a superposição de atribuições e competências entre os órgãos administrativos regionais; na reorganização da SEE, para a descentralização da execução das suas ações, agindo dentro desses princípios para a alteração da gestão educacional na perspectiva do gerencialismo e da racionalização organizacional.

Outra ação de destaque tomada pela SEE, sob a perspectiva da racionalização da gestão, com vistas ao enxugamento da estrutura organizacional da SEE e da rede de ensino e à implantação de um modelo de descentralização operacional foi a criação do Programa de Reorganização das Escolas da Rede Pública Estadual (SOUZA, 2002). Desse modo, logo em 1995, com previsão de funcionamento para 1996, o Ensino Fundamental e Médio, regular e supletivo, passou a ser oferecido, em unidades escolares organizadas com classes: de $1^{\mathrm{a}}$ a $4^{\mathrm{a}}$ série; de $5^{\mathrm{a}}$ a $8^{\mathrm{a}}$ série; 
de $5^{\text {a a }} 8^{\text {a }}$ série e de Ensino Médio; e de Ensino Médio apenas. O objetivo era agrupar os alunos por faixa etária para atender diferentes públicos, em escolas distintas, com vistas ao uso mais racional do atendimento pedagógico, do espaço físico e dos equipamentos escolares, inclusive pelo funcionamento da maioria das escolas em dois turnos diurnos ou em dois turnos diurnos e um noturno. Na prática, essa racionalização acabou servindo para a SEE justificar o fechamento de várias escolas estaduais, tendo em vista a otimização no uso dos espaços físicos e dos recursos materiais e humanos que causou essa medida (idem).

Ainda, dentro da perspectiva de racionalização da gestão, novas relações foram desenhadas pelo Estado de São Paulo entre os poderes públicos, entre o poder público e a sociedade, entre a Secretaria da Educação e as escolas e entre a sociedade e a escola. Dessa forma, no que diz respeito à alteração das relações entre o poder público e entre o poder público e a própria sociedade, destaca-se a criação do Programa de Ação de Parceria Educacional Estado-Município (NOVAES, 2009; RAMOS, 2008; VIRIATO, 2001). Ele foi instituído em 1996 para possibilitar o desenvolvimento do Ensino Fundamental paulista por meio de uma parceria entre os poderes executivos estadual e municipal, impulsionando o aumento da municipalização do ensino no Estado. Para tanto, por meio de um processo de adesão, era assinado um convênio entre o Estado e o município, ficando definidas as obrigações de cada uma das esferas dentro do processo, incluindo normatizações sobre: assistência técnica e financeira, financiamento geral, transferências e/ou empréstimos de bens (físicos e humanos), recursos materiais e humanos, capacitação de pessoal, contratação de pessoal, procedimentos de avaliação e acompanhamento do processo, entre outras. Destacam-se entre os objetivos dessa ação: a distribuição mais clara de responsabilidades entre Estado e municípios no tocante ao Ensino Fundamental, com grande repasse de tarefas para os municípios; a tentativa de fortalecimento do controle das atividades escolares pelas comunidades locais, tendo em vista sua proximidade do poder municipal; o estabelecimento da descentralização da gestão educacional com base no princípio da responsabilização social. Tal ação perdurou (e perdura) na história paulista durante todo o período estudado, servindo de base para a compreensão da relação estabelecida entre o poder público estadual e o poder público municipal no Estado no que diz respeito à gestão da educação.

Além da redefinição de papéis do poder público e da ampliação do princípio da responsabilização social, mais adiante, especialmente a partir de 2004, o foco passou notadamente para a redefinição mais clara das relações entre o poder público e a escola e entre a escola e a sociedade, pela ampliação do papel da escola frente à sociedade e pela ampliação do papel da sociedade frente à escola, avançando no sentido das ações de descentralização operacional, de racionalização 
de gastos e de responsabilização social iniciadas pelas medidas anteriores. Nesse sentido, pode-se enfatizar o Programa Escola da Família (LIBANORI, 2011). Ele foi instituído em 2004, visando à abertura das escolas públicas estaduais durante os finais de semana para atrair os jovens e seus familiares para participarem de ações socioeducativas variadas (artísticas, esportivas, recreativas, formativas e informativas). Ficava sob a responsabilidade da autoridade escolar o acompanhamento e o gerenciamento das referidas atividades.

O Programa Escola da Família contava com o apoio e o estabelecimento de parcerias e convênios (com organizações não governamentais, associações, empresas, sindicatos, cooperativas, instituições de Ensino Superior e outras instituições educacionais, e a participação de demais Secretarias de Estado), bem como com a participação de estudantes universitários - mediante a concessão de bolsas de estudo (Programa Bolsa-Universidade). Entre os seus objetivos destacam-se a ampliação da atuação e controle da comunidade local sobre a escola, bem como a utilização da escola como ferramenta de lazer para a comunidade numa ação de contenção da violência e da marginalidade no Estado de São Paulo.

Nessa mesma linha, destaca-se o programa Escola de Tempo Integral (PUCCI, 2005), que buscou alterar as relações entre o poder público e a escola e entre a sociedade e a escola. Ele foi criado em 2005, tendo como proposta ampliar o tempo diário de permanência do aluno na escola. Com ele, os alunos passaram a ficar por aproximadamente nove horas diárias nessas escolas, para participarem de atividades variadas divididas em dois turnos: um, com disciplinas do currículo básico; e outro, com oficinas temáticas. Fazia parte dos objetivos do programa assistir aos alunos em suas necessidades básicas e educacionais e proporcionar atividades que envolvessem os campos social, cultural, esportivo e tecnológico, para que a comunidade tivesse maior participação no processo educacional, ajustando a escola às demandas regionais $(\mathrm{BERGO}, 2014)$. Buscando mudar a relação da comunidade com a escola, otimizando a resolução de problemas sociais de responsabilidade do Estado, por dentro da escola, o foco desse programa eram as localidades mais carentes, situadas em regiões de baixo IDH (Índice de Desenvolvimento Humano).

Ambos os programas permaneceram (e permanecem) no Estado de São Paulo, solidificando-se enquanto mecanismos de ampliação das atribuições e do papel escolar ao terem em seus horizontes o objetivo da inclusão social pelo uso da escola, enquanto esfera mais econômica para materializar tal processo, e da redefinição explícita das relações entre o poder público e a escola e entre a escola e a sociedade. Além disso, por intermédio desses tipos de programas, posteriormente inseridos no Programa Educação-Compromisso de São Paulo, 
em 2011, reafirmou-se no Estado a tendência da SEE de induzir as escolas e o setor privado a realizarem parcerias entre si, tendência estabelecida desde 1995 pelo Projeto Escola em Parceria (ADRIÃO, 2008; ADRIÃO; GARCIA, 2014), cujo foco era gerenciar ações promovidas por instituições da sociedade civil (empresas privadas, organizações não governamentais (ONG) e outras associações), "fortalecendo a proposta pedagógica das Escolas Estaduais, por meio de projetos que representam custo zero para a Secretaria" (SÃO PAULO, 2013a, s/p).

Considerando essas ações de descentralização dos procedimentos operacionais postos em andamento pela SEE a partir de 1995, paralelamente, durante todo o período estudado, foram criados e mantidos mecanismos para o controle do Estado sobre a educação, configurando-se, assim, em São Paulo, um modelo de gestão tipicamente (des)centralizado, ou melhor, um modelo preciso de descentralização tutelada, deixando claro os limites entre o papel decisório assumido pelo Estado, na figura da Secretaria da Educação, e o papel operacional legado às gestões locais, às escolas e à comunidade nesse processo.

Destarte, não por acaso, desde 1995, já havia sido efetivado em São Paulo um amplo processo de informatização da rede administrativa da educação. Ele foi iniciado no $2^{\circ}$ semestre do referido ano, com a implantação do Sistema de Cadastro de Alunos do Estado de São Paulo (NEUBAUER, 1999) e com a descentralização de verbas, pelo governo paulista, em 1996, destinada à compra de microcomputadores e impressoras pelas escolas para a informatização dos procedimentos administrativos da unidade escolar. Esse programa era voltado para a ação de informatização da gestão da escola, possibilitando à Secretaria maior facilidade e rapidez para ter acesso aos dados sobre o ensino paulista, tendo em vista a descentralização de sua gestão operacional. Dessa forma, informações como folha de frequência de professores, anotações da vida funcional das escolas, lista de notas e faltas dos alunos foram integradas a um sistema central de gestão e acompanhamento, permitindo à SEE o acesso a informações essenciais para a efetivação de sua política de racionalização organizacional e de gastos, de reforma nos padrões de gestão e de mudanças nos padrões pedagógicos escolares.

Outra ação de grande impacto no quesito (des)centralização da gestão foi a implantação do Sistema de Avaliação do Rendimento Escolar do Estado de São Paulo (SARESP) (ARCAS, 2009; BAUER, 2006). Ele foi criado em 1996, tendo como foco a avaliação anual do desempenho dos alunos do Ensino Fundamental e Médio do Estado de São Paulo, pautando-se nos Parâmetros Curriculares Nacionais para definição de suas matrizes de referência (BARROS; TAVARES; MASSEI, 2009). Seu objetivo era verificar o rendimento dos alunos em diferentes componentes curriculares, sendo 
voltado para todas as escolas da rede estadual e para as redes municipal e particular que aderissem à proposta. Desse modo, com ele, eram disponibilizados dados sobre a qualidade do ensino paulista para a SEE, as Diretorias de Ensino, as escolas, os estudantes e seus familiares e a sociedade civil como um todo, estabelecendo-se como uma estratégia de controle indireto do processo de ensino e de imputação de responsabilidades às escolas sobre os resultados alcançados.

Esse sistema avaliativo perdurou (e perdura) durante todo o período estudado com grande destaque na rede paulista, tendo recebido remodelações para manutenção de sua coerência com as especificidades conjunturais das políticas de cada gestão governamental estudada. Assim, destaca-se que, em 2008, os exames nas áreas de Língua Portuguesa e Matemática permaneceram anuais e alternaram-se os exames nas diferentes áreas de Ciências Humanas e de Ciências da Natureza, sofrendo alterações no próprio modelo da prova em razão da nova Proposta Curricular do Estado de São Paulo aprovada no período e atrelada ao programa "São Paulo faz Escola".

O SARESP também foi associado, posteriormente, a políticas como IDESP (Índice de Desenvolvimento da Educação do Estado de São Paulo) e bonificação por resultados dos integrantes do quadro do magistério, aumentando o potencial de controle do Estado sobre os rumos da educação frente à gestão proposta. Para tanto, em 2008, foram instituídos o Programa de Qualidade da Escola (PQE) e o IDESP. O PQE tinha por objetivo a fixação de metas de qualidade de ensino para cada unidade escolar paulista (SILVA, 2013). Por isso, foi criado o IDESP, instrumento usado como parâmetro para a definição das metas educacionais, por escola, com base no cálculo relacional entre desempenho dos alunos no SARESP e fluxo escolar (idem). Ele foi definido como mecanismo para subsidiar o cálculo das metas de rendimento a serem fixadas para cada unidade escolar estadual e como ação 'motivacional' para escolas e seus profissionais, ao estabelecer um parâmetro externo para atribuição da bonificação por desempenho ou mérito às unidades de ensino e seus profissionais. Não por acaso, algumas escolas passaram a tomar as provas do SARESP como conteúdo de ensino após essa medida (ARCAS, 2009).

Com todas essas ações implantadas, em 2011, foi a própria Secretaria da Educação que se reestruturou no sentido do aprimoramento do que eles passaram a chamar de Gestão de Resultado com Foco no Desempenho do Aluno (SÃO PAULO, 2013b, p. 64). Desse modo, foram organizadas seis coordenadorias, que passaram a atuar em áreas específicas (Gestão de Recursos Humanos; Orçamento e Finanças; Infraestrutura e Serviços Escolares; Formação e Aperfeiçoamento; Ensino Básico; Informação, Monitoramento e Avaliação Educacional), que antes estavam divididas como tarefas de diferentes setores. 
Destarte, segundo a própria concepção da proposta, essa reestruturação se organizou em torno de quatro linhas principais, que nada mais fizeram do que reforçar o modelo de gestão impresso no Estado desde 1995, ou seja: da centralização na definição de políticas e metas educacionais, na proposição do conteúdo educacional, na organização do ano letivo, na definição de políticas, diretrizes e normas, na aplicação e gestão dos recursos; da descentralização na execução do ensino e da aprendizagem, na aplicação e no gerenciamento de recursos locais; da articulação na definição das prioridades, estratégias e políticas e na gestão de recursos e realização de políticas; da responsabilização para alcance dos resultados e metas da educação e monitoramento e avaliação dos resultados (SÃO PAULO, 2013b).

Todas essas ações, como se nota, buscaram imprimir no Estado a alteração de sua gestão educacional para um modelo (des)centralizado, tendo por fundamento o princípio da racionalização de gastos e procedimentos, mantendo simultaneamente a tutela estatal sobre os seus resultados e a ampliação da responsabilização da escola e da comunidade sobre eles, potencializando o papel fiscalizador da comunidade sobre a educação escolar de São Paulo. Com isso, foi apresentada claramente a tentativa oficial de construção de uma política de qualidade de ensino pautada sob bases gerencialistas e racionais de funcionamento e de gastos com o setor, tendo como estratégias centrais: a alteração da organização pedagógica e curricular do ensino, que tinha como princípio a estrutura educacional enxuta posta pelas políticas educacionais apresentadas, e a responsabilização dos profissionais da educação, notadamente dos professores, pelos resultados alcançados por elas.

\section{Racionalização organizacional e mudança no padrão de gestão como princípios da qualidade do ensino}

A qualidade, dentro de um modelo gerencial, tem entre suas características básicas, conforme Bresser Pereira (1996), o abandono de procedimentos e do controle rígido sobre o passo a passo dos processos administrativos. $\mathrm{O}$ comando, então, passa a se instaurar por meio de um processo de controle do produto final, ou seja, a posteriori, definindo-se previamente os seus responsáveis, bem como premiando e punindo conforme os resultados alcançados (idem). Segundo Souza Filho (2009), sob essa perspectiva, redefine-se a relação de controle que passa a se dar pela junção de descentralização, performatividade e controle de resultados.

Destarte, o eixo qualidade do ensino, adotado pela reforma educacional paulista, apresenta de forma clara e forte a presença do princípio da racionalização organizacional e de gastos com o setor, segundo o modelo gerencialista assumido, tendo por base a performatividade e o controle de resultados. Nesse caso, as ações 
agiram basicamente em dois aspectos principais, sendo: a) na reorganização pedagógica e curricular do ensino, sob moldes mais coerentes ao processo de racionalização posto pelas políticas voltadas a mudar o padrão de gestão da educação no Estado, b) e na capacitação, remuneração ou carreira dos profissionais da educação, como estratégia emergencial de atuação sobre esses profissionais (especialmente o docente), a despeito do investimento desproporcional para o seu alcance. Em ambos os casos, o que se destacava era o uso de estratégias financeiramente mais baratas para ação na qualidade do ensino, tentando-se mudar o modelo educacional no Estado por meio de alterações em sua organização e pela imposição desse modelo aos professores como "referência" para suas práticas cotidianas.

No que diz respeito às ações voltadas para a alteração da organização pedagógica da escola, destaca-se inicialmente a divisão do Ensino Fundamental em dois ciclos, em substituição ao modelo de organização seriada. Assim, o Ensino Fundamental foi organizado, em 1997, em dois ciclos de aprendizagem (RAMOS, 2008): ciclo I ( $1^{\mathrm{a}}$ a $4^{\mathrm{a}}$ séries $)$ e ciclo II ( $5^{\mathrm{a}}$ a $8^{\mathrm{a}}$ séries). $\mathrm{O}$ argumento era que, com os ciclos, o ensino ficaria mais flexível e o aluno poderia se desenvolver dentro de etapas mais longas e menos rígidas do que as séries. Para isso, o modelo de avaliação previsto foi o contínuo (idem), almejando verificar processualmente o cumprimento dos objetivos do ciclo. Para além das questões notadamente pedagógicas declaradas, nota-se por trás dessas medidas o interesse claro de se agir nos números da qualidade do ensino por meio de sua flexibilização, reduzindo quantitativamente os números de evasão e de repetência escolar, coerentemente ao princípio da racionalização de gastos encontrado como parte dos eixos centrais dessa reforma.

Em 2014, com a expansão do tempo de duração do Ensino Fundamental de oito para nove anos feita por ação federal, este passou a ter no Estado sua organização curricular desenvolvida em regime de progressão continuada estruturada em nove anos, divididos em três ciclos: Ciclo I ( $1^{\circ}$ ao $3^{\circ}$ ano), Ciclo II ( $4^{\circ}$ ao $6^{\circ}$ ano) e Ciclo III ( $7^{\circ}$ ao $9^{\circ}$ ano). Em razão dessa flexibilização instaurada no Estado desde 1997, os ciclos associaram-se diretamente, desde o início de sua implantação, ao uso oficialmente induzido de metodologias de ensino pautadas em "pedagogias do aprender a aprender"3 - na medida em que estas têm a flexibilização da aprendizagem em suas bases (MARSIGLIA, 2011, p. 133) - e ao princípio da política de Progressão Continuada.

Duarte $(2000,2001)$ chama de pedagogias do aprender a aprender certos ideários educacionais que trazem em suas bases: a desvalorização do ensino; a desvalorização do conhecimento historicamente construído pela humanidade; a desvalorização da diretividade no processo educativo; a desvalorização de uma educação que se proponha questionar e transformar a sociedade capitalista. São destacadas, pelo autor: a pedagogia das competências, o construtivismo, a Escola Nova, os estudos na linha do professor reflexivo, dentre outras. 
O regime de Progressão Continuada (ARCAS, 2009; PAULA, 2012) no Ensino Fundamental, como se percebe, aparece então como estratégia para sustentar o regime de ciclos em São Paulo. Ele foi implantado em 1997, sendo instaurado em 1998 em todas as escolas estaduais. Seu funcionamento deu-se pela prévia organização do Ensino Fundamental em dois ciclos: ciclo I ( $1^{\mathrm{a}}$ a $4^{\mathrm{a}}$ séries $)$ e ciclo II ( $5^{\mathrm{a}}$ a $8^{\mathrm{a}}$ séries $)$. A ideia era a de que, com os ciclos de progressão continuada, fosse inibida a prática da reprovação do aluno (e, por conseguinte, a repetência e a evasão escolar) pela consideração de seu ritmo, de modo que ele pudesse se desenvolver dentro de etapas mais longas e menos rígidas de aprendizagem. Com isso, a reprovação passou a ocorrer basicamente apenas ao final de cada ciclo, quando, por motivos de insuficiência no desempenho e na frequência, o aluno poderia ser retido e encaminhado para classes de recuperação de ciclo, nas quais poderia permanecer no máximo por dois anos.

Essa junção entre ciclos e progressão continuada, em São Paulo, acabou servindo de estratégia preventiva para lidar, sobretudo de forma quantitativa, com o problema da evasão e repetência escolar, atuando em sua redução numérica ano a ano e, por conseguinte, na redução dos gastos com reinvestimento em alunos - não obstante os baixos resultados de ensino alcançados no período 4 . Para se ter uma ideia sobre essa redução, é importante destacar que, enquanto em 1996 a taxa de reprovação e evasão de alunos das escolas estaduais era de 452.296 e 340.286 no Ensino Fundamental, em 2001, ou seja, em apenas cinco anos, esses números baixaram para 183.564 e 108.361, respectivamente (BRASIL, 1997, 2002) (Quadro 1).

Nessa mesma linha de atuação, tal tendência preventiva foi reafirmada, em 2007, no novo Plano Estadual de Educação, dentre suas 10 metas, intensificando-se, sobretudo, após a criação do IDESP, em 2008, que, associado a uma política de bonificação do magistério por resultados, passou a "premiar" escolas e docentes com as melhores notas no referido índice. Para tanto, considerava-se para o cálculo desse índice dois critérios fundamentais, o desempenho da escola (calculado a partir dos resultados do SARESP sobre o desempenho dos alunos do Ensino Fundamental e Médio nas áreas avaliadas no exame, conforme dito antes) e o fluxo escolar (calculado com base nos dados do Censo Escolar sobre aprovação/reprovação de alunos no Ensino Fundamental e Médio por escola) (BARROS, TAVARES, MASSEI, 2009).

Outra medida importante para a alteração da organização pedagógica do ensino, tendo por base ações de racionamento de gastos no setor, foi a criação das Classes

\footnotetext{
Conforme o INEP - Instituto Nacional de Estudos e Pesquisas Educacionais (BRASIL, 2007), as médias de proficiência em língua portuguesa no SAEB (4a série do Ensino Fundamental - escolas urbanas estaduais de São Paulo) caíram de 190,6, em 1995, para 166,9, em 2001, e de proficiência em matemática, caíram de 193,6, em 1995, para 180,5, em 2001.
} 
Quadro 1. Comparação das taxas de reprovação e evasão de alunos do Ensino Fundamental das escolas estaduais de São Paulo nos anos de 1996 e 2001.

\begin{tabular}{|l|c|c|}
\hline Ano & Reprovação & Evasão \\
\hline 1996 & 452.296 & 340.286 \\
\hline 2001 & 183.564 & 108.361 \\
\hline
\end{tabular}

Fonte: BRASIL, 1997, 2002.

de Aceleração (VIEIRA, 2002), em 1996. Elas eram salas de aulas específicas para os alunos com defasagem idade-série, objetivando avançá-los em seu percurso escolar e reintegrá-los ao fluxo regular. Ao final do período letivo, os professores responsáveis pelas classes emitiam um parecer conclusivo a respeito de cada aluno, indicando qual seria a sua classe de destino. O aluno da Classe de Aceleração I poderia ser encaminhado à Classe de Aceleração II, à $4^{\mathrm{a}}$ série ou à $5^{\mathrm{a}}$ série do Ensino Fundamental. Já o aluno da Classe de Aceleração II poderia ser encaminhado à $4^{\mathrm{a}}$ série ou $5^{\mathrm{a}}$ série do Ensino Fundamental. Com essa ação, o Estado acabou conseguindo agir de forma remediativa nos números de evasão e repetência já instalados em São Paulo, atuando em sua redução numérica e, consequentemente, nos gastos com reinvestimento em alunos.

Entretanto, essas ações não foram suficientes para melhorar efetivamente os resultados da qualidade do ensino no Estado verificados nas avaliações estaduais e nacionais de desempenho, e estes passaram a ser usados como ferramenta de crítica ao governo ${ }^{5}$, provocando ações posteriores mais radicais por parte das gestões subsequentes de São Paulo, no sentido de agir mais diretamente no controle do conteúdo e do método de ensino nas salas de aula por intermédio da ação direta e intensiva sobre o trabalho docente (com políticas de capacitação diretiva, de bonificação por desempenho, de distribuição de cadernos com orientações pedagógicas e de conteúdo para o professor, entre outras).

Nesse contexto, as gestões posteriores tentaram achar novos mecanismos para a promoção dos bons índices educacionais, sem abrir mão do princípio da racionalização organizacional e de gastos com a educação em seu modelo de gestão descentralizada e fortemente tutelada. Por isso, não por acaso, a atuação no trabalho docente e em sua capacitação passou a ser utilizada como estratégia mais econômica para essa ação, cerceando ainda mais intensamente a autonomia pedagógica do professor.

Podem ser destacadas, como exemplos, as seguintes notícias: "Cesar Callegari critica a política educacional do Estado no Dia do Professor" (FOLHA DE SÃO PAULO, 2007). 
Pretendendo agir diretamente na condução da prática pedagógica, com forte ênfase no conteúdo e na prática do ensino, pode ser destacado o programa "São Paulo faz Escola" (CATANZARO, 2012; FIAMENGUI, 2008). Sobre isso, é importante considerar-se que, em 2008, foi criada a Proposta Curricular do Estado de São Paulo para o Ensino Fundamental e para o Ensino Médio, que, complementando e ampliando as Diretrizes e os Parâmetros Curriculares Nacionais, passou a se constituir no referencial básico obrigatório para a formulação da proposta pedagógica das escolas da rede estadual (CATANZARO, 2012; FIAMENGUI, 2008; PAULA, 2012). Tais propostas foram complementadas por um conjunto de documentos, com orientações didáticas e expectativas de aprendizagem, distribuídos por níveis de ensino, anos e séries.

O material do programa "São Paulo faz Escola" se enquadrou, nesse sentido, como material de base para a implementação da proposta. Ele trabalhou com o currículo previsto, servindo de ferramenta de apoio para os alunos e professores das escolas estaduais de $5^{\mathrm{a}}$ a $8^{\mathrm{a}}$ séries do Ensino Fundamental e Médio. Seu objetivo era que os professores tivessem um conteúdo fixo a ser aplicado a cada bimestre, tendo em vista os índices e instrumentos de avaliação educacional previstos no Estado (SARESP e IDESP). Ele foi inicialmente apresentado e enviado às escolas, em 2008, sendo composto pelo Jornal do Aluno e pela Revista do Professor. A indicação era de que esse material fosse usado nos primeiros 40 dias letivos do ano de 2008 (entre os dias 18 de fevereiro e 30 de março de 2008), para auxiliar professores e alunos na realização das atividades em sala de aula durante o denominado Programa Intensivo no Ciclo (PIC), tendo como conteúdo básico a leitura, a produção de textos e a matemática.

O material foi dividido em Ensino Fundamental e Médio, por disciplina/série e apresentava o número específico de aulas necessárias para cada conteúdo pré-determinado, bem como detalhes sobre as possibilidades de aplicação e de avaliação das atividades propostas para o aluno portador do Jornal. Todavia, ainda em 2008, a SEE enviou um novo material para a escola (Cadernos do Professor), em formato cartilha, indicando os conteúdos a serem trabalhados pelo professor naquele ano letivo. Nesse material, estava explicitada a nova Proposta Curricular definida para todo o Estado. Posteriormente, foram enviados às escolas os cadernos/ apostilas para os alunos, que passaram a utilizá-los como material didático.

Vale frisar que ação parecida foi desenvolvida para o caso específico dos anos iniciais do Ensino Fundamental, em 2007. O programa Ler e Escrever foi criado nesse ano, objetivando, dentre outras coisas, fornecer um conjunto de ações articuladas, bem como orientações curriculares a serem seguidas pelas escolas, com 
vistas à alfabetização dos alunos (CONSTANCIO, 2012). Assim, esse programa desenvolveu ações, incluindo formação, acompanhamento, elaboração e distribuição de materiais pedagógicos para os profissionais envolvidos com a alfabetização paulista, dentre outras atividades. No caso específico da capacitação promovida pelo programa Ler e Escrever, vale destacar que os cursos eram destinados a todos os profissionais envolvidos no programa, sobretudo os professores, agindo no sentido de instrumentalizá-los para a operacionalização da proposta.

Destarte, o que se nota é que, por meio desses programas (São Paulo faz Escola e Ler e Escrever), a autonomia docente, que já havia sido limitada pelas políticas anteriores - que se impuseram à rede, atreladas a um modelo pedagógico pré-definido (MARSIGLIA, 2011) -, acabou ainda mais tolhida, tendo em vista que tais ações definiram não apenas os conteúdos de ensino, mas as expectativas de aprendizagem para os alunos, por meio da definição de um modelo educacional bastante detalhado (fixava o dia a dia escolar dentro das cartilhas voltadas para professores e alunos), referendado em "pedagogias do aprender a aprender" e no desenvolvimento de competências e habilidades nos alunos (CONSTANCIO, 2012; PAES, 2012).

Tendo em vista toda essa reorganização pedagógica e curricular no Estado, a capacitação docente passou a ser focada como estratégia central para o alcance dos índices de ensino. O professor começou a ser tratado, nessa perspectiva, como agente principal responsável pelos resultados da qualidade do ensino no Estado, com vistas ao fortalecimento de um processo de eficiência operacional, dentro do modelo gerencialista assumido. Entretanto, o veículo mais utilizado no processo de capacitação docente foi o de educação a distância e o conteúdo dessa sua formação passou a estar diretamente ligado ao seu condicionamento para atuação no novo modelo educacional disseminado no Estado. Dessa forma, foram criados vários programas, focalizando a capacitação dos profissionais da educação da rede - com destaque para os professores nesse grupo -, para atuação dentro dos novos moldes organizacionais e pedagógicos postos, agindo de forma mais intensa no processo de cerceamento da autonomia pedagógica e profissional.

Essa ação foi utilizada logo nas primeiras gestões do período e intensificada com o passar do tempo, quando os números da educação no Estado não ascenderam ou pouco ascenderam. Sobre isso, é interessante observar que, segundo o INEP (BRASIL, 2007, p. 11-2), dados revelam que entre os anos de 1995 a 2001, as médias de proficiência em língua portuguesa alcançadas pelos alunos da $4^{\mathrm{a}}$ série do Ensino Fundamental das escolas urbanas estaduais de São Paulo no SAEB (Sistema de Avaliação da Educação Básica) foram de 190,6, em 1995, 182,3, em 1997, 172,9, em 1999, chegando a 166,9, em 2001. No caso da proficiência 
em matemática, os resultados não ficaram distantes disso, saindo da média de 193,6, em 1995, 186,8, em 1997, 184,6, em 1999, caindo para 180,5, em 2001, como mostra o Quadro 2.

A partir de 2003, a proficiência em português melhorou, saindo de 166,9, em 2001, indo para 176,8, em 2003, e para 177,9, em 2005. No mesmo período, a proficiência em matemática melhorou de maneira singela, saindo de 180,5, em 2001, indo para 181,9, em 2003, e para 182,9, em 2005.

Apesar da melhora ascendente das notas verificadas no Quadro 3, o que se observa é que, considerando-se os Quadros 2 e 3, ou seja, contabilizando o período de 1995 a 2005, não houve recuperação das médias anteriores à implementação da maior parte das políticas do período, de modo que os valores de 190,6, em português, e de 193,6, em matemática, obtidos no ano de 1995, não foram ultrapassados ou recuperados, conforme mostra o Quadro 4.

Destarte, desde 1997, a focalização no docente, com o pressuposto de ser ele o agente central responsável pelos resultados educacionais, pode ser percebida no Programa de Educação Continuada (PEC) (RAMOS, 2008), cuja finalidade

Quadro 2. Médias de proficiência em língua portuguesa e matemática alcançadas pelos alunos da $4^{\mathrm{a}}$ série do Ensino Fundamental das escolas urbanas estaduais de São Paulo no Sistema de Avaliação da Educação Básica em 1995, 1997, 1999 e 2001.

\begin{tabular}{|l|c|c|}
\hline Ano & Língua Portuguesa & Matemática \\
\hline 1995 & 190,6 & 193,6 \\
\hline 1997 & 182,3 & 186,8 \\
\hline 1999 & 172,9 & 184,6 \\
\hline 2001 & 166,9 & 180,5 \\
\hline
\end{tabular}

Fonte: BRASIL, 2007.

Quadro 3. Médias de proficiência em língua portuguesa e matemática alcançadas pelos alunos da $4^{\mathrm{a}}$ série do Ensino Fundamental das escolas urbanas estaduais de São Paulo no SAEB em 2001, 2003 e 2005.

\begin{tabular}{|l|c|c|}
\hline Ano & Língua Portuguesa & Matemática \\
\hline 2001 & 166,9 & 180,5 \\
\hline 2003 & 176,8 & 181,9 \\
\hline 2005 & 177,9 & 182,9 \\
\hline
\end{tabular}

Fonte: BRASIL, 2007. 
central era oferecer ações de capacitação a todos os que atuassem junto aos alunos (supervisores, assistentes técnico-pedagógicos, diretores de escola, professores-coordenadores e professores), para a execução das políticas em processo. Ainda, integrando o PEC (Programa de Educação Continuada), foi criado o Programa de Educação Continuada - Universitário (PEC-Universitário) (idem), em 2001, com o objetivo específico de oferecer formação em nível superior aos docentes dos anos iniciais do Ensino Fundamental da rede estadual de ensino, atendendo uma exigência legal e, ao mesmo tempo, apresentando novos referenciais de ensino para o professor.

Atuando na linha específica da capacitação docente, foi criado o programa Letra e Vida (RAMOS, 2008). Ele se tratava de uma reedição feita, em 2005, pela SEE, do Programa de Formação de Professores Alfabetizadores (PROFA), criado pelo MEC no início do ano de 2001. Era constituído por um conjunto de materiais (apostilhas, vídeos, guias, etc.) cuja finalidade era promover a capacitação dos professores a partir de uma fundamentação construtivista (construtivista-interacionista ou de socioconstrutivista, como nomeava) no que se referia ao ensino e à aprendizagem da leitura e da escrita, relacionando os conteúdos abordados e suas decorrências para a prática pedagógica docente, dentro do referencial pedagógico assumido (idem).

Outro programa voltado para a capacitação docente foi o Rede do Saber (PALMA FILHO, 2009). Criado em 2003, seu foco era a formação em nível superior daqueles professores efetivos da $1^{\mathrm{a}}$ a $4^{\mathrm{a}}$ série da rede pública estadual de ensino que ainda não a possuíam. Posteriormente, a proposta foi ampliada, voltando-se também para a formação continuada dos profissionais da educação de todo o Estado, amparando-se em recursos tecnológicos (videoconferência, teleconferência, etc.). Destacam-se como programas que utilizavam a Rede do Saber, dentre outros: a) A Rede Aprende com a Rede - RAR (2008-2009; 2009-,em andamento) marcado para a formação continuada dos professores da rede estadual, com enfoque para questões metodológicas e conceituais da Proposta Curricular para o Estado de São Paulo. Posteriormente, além de seu formato anterior, passou a trazer três

Quadro 4. Comparação das médias de proficiência em língua portuguesa e matemática alcançadas pelos alunos da $4^{\text {a }}$ série do Ensino Fundamental das escolas urbanas estaduais de São Paulo no Sistema de Avaliação da Educação Básica em 1995 e 2005.

\begin{tabular}{|l|c|c|}
\hline Ano & Língua Portuguesa & Matemática \\
\hline 1995 & 190,6 & 193,6 \\
\hline 2005 & 177,9 & 182,9 \\
\hline
\end{tabular}

Fonte: BRASIL, 2007. 
cursos paralelos e interligados: RAR PEB II, para professores; RAR-Mediação, para Professor Coordenador de Oficinas Especiais (PCOPs) de Currículo; e RAR-Educação a Distância, para PCOPs de Tecnologia; b) PEC-Formação Universitária Municípios - $1^{\mathrm{a}}$ edição (2003-2004) e $2^{\mathrm{a}}$ edição (2006-2007), assim como o PEC-Formação Universitária, que objetivava oferecer uma graduação presencial com apoio de mídias interativas para professores de educação infantil e da $1^{\mathrm{a}}$ a $4^{\mathrm{a}}$ série do Ensino Fundamental; c) Letra e Vida (2003-em andamento), que pretendia realizar a formação continuada de professores alfabetizadores, pautando-se em práticas presenciais e videoconferências.

O programa Bolsa Mestrado (RAMOS, 2013), posteriormente ampliado para programa Bolsa Mestrado e Doutorado, também pode ser destacado dentro das ações diretamente voltadas para a capacitação do profissional da rede. Ele se diferencia dos outros por focar a formação em pós-graduação, tendo como limitante o fato de que os temas a serem trabalhados pelos pós-graduandos deveriam estar associados aos interesses da Secretaria para sua concessão. Foi instituído em 2003, integrando o Programa de Formação Continuada de Educadores - Teia do Saber da SEE (ABRAHÃO, 2006). Ele dirigia-se aos titulares de cargo efetivo do Quadro do Magistério da Secretaria da Educação, com licenciatura plena e em efetivo exercício nas unidades da rede pública estadual, que podiam optar por diferentes benefícios do programa.

A partir de 2008, o programa Bolsa Mestrado e Doutorado teve ampliados os seus critérios para participação e a bolsa tornou-se um benefício fixo. Todavia, manteve-se a prática do direcionamento do tema de estudo do profissional: quando o curso de pós-graduação tivesse por objeto a disciplina do cargo exercido pelo servidor, o projeto de pesquisa deveria estar dirigido para o desenvolvimento de metodologias de ensino e aprendizagem da respectiva disciplina, bem como incluído nas linhas de pesquisa definidas pela Secretaria da Educação; por outro lado, quando o curso de pós-graduação fosse em educação, o projeto de pesquisa deveria voltar-se para a área de gestão escolar, no caso de diretor de escola, para a área de supervisão escolar, no caso de supervisor de ensino, ou para o desenvolvimento de metodologias de ensino e aprendizagem referentes à disciplina do cargo exercido pelo profissional, no caso de professor, segundo as linhas de pesquisa definidas pela Secretaria (SÃO PAULO, 2008a). Com isso, direcionava-se inclusive o enfoque específico da formação em pós-graduação pelo sujeito, conforme interesses externos da Secretaria.

Outras ações na qualidade do ensino acabaram impactando fortemente na capacitação e na carreira do profissional. Esse foi o caso do Programa + Qualidade na Escola 
(RAMOS, 2013; SILVA, 2013), lançado em 2010, que, dentre outras coisas, criou a Escola de Formação de Professores do Estado de São Paulo (RAMOS, 2013; SILVA, 2013), que oferecia curso obrigatório (de 360 horas de formação durante quatro meses com atividades em classe e práticas escolares) para os novos professores da rede pública. A ideia era que o curso fosse exigência básica, além do concurso público, para a contratação de professores, diretores e supervisores. Durante o curso, os profissionais receberiam $75 \%$ do salário inicial da categoria. Os professores temporários também deveriam passar pelo exame obrigatório. Ele seria o requisito para que os docentes atuassem em sala de aula, e a atribuição de aulas aconteceria de acordo com os resultados da prova anual, além da consideração de requisitos como tempo de serviço e titulação. Até o ano de 2013, só seriam admitidos para dar aulas aqueles que fossem aprovados no exame. Os reprovados, que tivessem garantia de estabilidade prevista em lei, ficariam com funções auxiliares (como atividades em salas de leitura, infocentros e em programas de parceria com a comunidade), com jornada mínima de 12 horas semanais.

Vale salientar que a prova direcionada aos temporários era eliminatória, sendo que o candidato precisava acertar ao menos 40 das 80 questões do exame. Todavia, posteriormente, o critério 'eliminatório' foi relativizado e alterado para 'classificatório', porque o Estado precisou chamar inclusive os reprovados para atuação em sala de aula, uma vez que faltavam docentes na rede (CANCIAN, 2013). Em termos de estrutura, o curso dividia-se em duas partes principais. A primeira focava o funcionamento da política educacional estadual implantada a partir de meados dos anos 1990; já a segunda, era voltada para área específica de atuação do docente, sendo abordada, em termos de conteúdos e de metodologia, por meio das definições do programa São Paulo faz Escola. Com isso, ao invés de serem aprimorados os processos de entrada de novos docentes no Estado, foi criado um funil de ingresso na rede paulista, tendo como critério de corte a frequência e a aprovação no curso oferecido pelo Estado (e em seus moldes) em detrimento da formação inicial docente nos cursos de licenciatura.

Nesse período, ainda que o salário do profissional da educação não tenha recebido grande destaque, uma política de bonificação foi criada para o seu incremento; todavia, com estratégias meritocráticas de funcionamento, coerentemente à lógica gerencial implantada. Destarte, já em 2001, foi estabelecida uma política de bonificação para o magistério (LOUREIRO, 2011), que ponderava apenas os critérios de assiduidade e frequência para realização do pagamento. Seu aprimoramento começou a se dar em 2006, com a inclusão de novos elementos para a formação de uma política clara de Bonificação por Resultados. A partir de então, as unidades de ensino e administrativas passaram a ser submetidas a uma avaliação, destinada a apurar os resultados obtidos, de acordo com os indicadores e metas estabelecidos 
pela Secretaria. Os indicadores usados buscavam, dentre outras coisas, captar o desempenho da instituição no tocante aos números da qualidade do ensino. Ainda, indicadores de desenvolvimento gerencial e de absenteísmo também eram considerados no cálculo, buscando reduzir o número das faltas docentes, sem, contudo, tentar verificar, entender ou atuar em suas causas efetivas.

Desse modo, em 2006, passaram a ser usadas como critérios para bonificação a média dos resultados dos indicadores de desenvolvimento do conjunto das escolas jurisdicionadas nas respectivas Diretorias de Ensino somada à aferição da frequência individual e à participação do profissional no Programa de Formação Continuada da Secretaria da Educação. A partir de 2007, os critérios foram reajustados para se fazer a bonificação, sendo: avaliação do desenvolvimento da escola (medido pelo indicador de permanência e sucesso escolar estabelecido por meio da verificação das taxas da escola de aprovação, reprovação e abandono); frequência; participação do profissional em Programas de Educação Continuada. Ainda que a consideração do critério formação como veículo de valorização pareça bem interessante, no caso da referida política, vale frisar que essa valorização ficou restrita apenas à participação nos cursos oferecidos pela própria SEE. Esse critério, bem como o da avaliação do desempenho da escola e o da frequência mantiveram-se em 2008; entretanto, a eles foi acrescido o critério assiduidade. Não por acaso, nesse momento, o foco para a concessão de bônus acabou sendo a exigência da presença do professor na sala de aula, pois o fator presença (frequência mais assiduidade) passou a corresponder a aproximadamente $70 \%$ da pontuação máxima (SÃO PAULO, 2008a).

Contudo, no final de 2008, os indicadores específicos e critérios de apuração e avaliação definidos pela Secretaria se compactaram nos resultados do Índice de Desenvolvimento da Educação do Estado de São Paulo (IDESP) (LOUREIRO, 2011; RAMOS, 2013; SILVA, 2013). Em linhas gerais, ocorria que, se a escola atingisse somente metade das metas, os funcionários recebiam apenas a metade do bônus; se a escola atingisse todas as metas, todos os funcionários da escola recebiam o total do bônus: $20 \%$ dos 12 salários mensais. Esse bônus foi desvinculado dos vencimentos ou do salário do servidor, que o receberia somente nos casos de cumprimento das metas fixadas pelo poder central do Estado e que seriam aferidas pelos dados de fluxo escolar do Censo Escolar e pelos números alcançados no SARESP, contribuindo para que o ensino em sala de aula se guiasse cada vez mais pelas matrizes de referência definidas pela SEE dentro dessa avaliação. Todavia, além das metas individuais, levando em consideração o IDESP alcançado na relação SARESP/fluxo escolar, o critério frequência manteve-se (SÃO PAULO, 2008b). O primeiro critério ficou como regulador da bonificação recebida; já o segundo ficou como exigência para poder receber o bônus, uma vez que sem a 
frequência mínima estipulada, mesmo que se alcançasse a meta proposta, não se teria o direito ao recebimento do bônus.

No ano seguinte, 2009, outra política de grande impacto na remuneração e carreira docente foi criada, reforçando as estratégias de controle das faltas docentes pelo mecanismo da premiação-punição. Esse foi o caso do Programa de Valorização pelo Mérito (MARQUES, 2012), que vinculou a progressão vertical na carreira à frequência/assiduidade e à avaliação de desempenho teórico do profissional. Esse programa estabeleceu a possibilidade de progressão na carreira dentro de intervalos de três ou quatro anos, segundo a classe integrante, àqueles que se submetessem a uma prova teórica (sobre conteúdos curriculares das disciplinas, práticas didáticas e conhecimentos pedagógicos) e fossem bem avaliados. Entretanto, dentro da gestão de racionamento de verbas praticado, cabe frisar que, para participar dessa prova, o profissional precisaria ter no mínimo $80 \%$ dos pontos previstos na tabela de frequência/assiduidade; ainda, essa progressão restringia-se a apenas $20 \%$ do contingente total dos integrantes de cada uma das faixas docentes.

Posteriormente, em 2011, essa política definiu um intervalo de quatro, cinco ou seis anos, segundo a classe, para esse tipo de progressão, bem como incluiu a possibilidade de escolha entre prova teórica ou prova prática, no formato memorial. Contudo, ficou mantida a determinação de que, para fazer a referida prova, o profissional precisaria ter os pontos definidos na tabela de frequência/assiduidade, novamente sinalizando para a resolução do problema do absentismo docente pelo caminho da punição.

Essas ações, como se nota, acabaram imprimindo no Estado uma política de qualidade de ensino pautada sob bases gerencialistas e racionais de funcionamento e de gastos com o setor, tendo como estratégias centrais: a alteração da organização pedagógica e curricular do ensino e a responsabilização dos profissionais da educação, notadamente dos professores, pelos resultados alcançados por elas. A partir desse modelo foi se consolidando, portanto, um modelo de gestão baseado na (des) centralização aliada à performatividade e ao controle dos resultados em educação.

\section{Nota final}

Passados mais de 20 anos desde o início da primeira gestão Covas, o que se percebe é que, apesar de certas nuanças administrativas, com variações de enfoques, de políticas e de programas educacionais, é notável que São Paulo manteve, desde 1995, coerência gerencial em sua estrutura, tendo o campo superestrutural da educação guiado por diretrizes básicas, como as de alterações nos padrões de gestão, racionalização organizacional e melhoria da qualidade do ensino (RAMOS, 2013). 
Assim, não obstante as diferenças conjunturais, o modelo de gestão integralmente assumido desde o início do governo Covas não foi alterado, mantendo-se ancorado sobre o princípio do gerencialismo e do racionamento e agregando ao setor público princípios, valores e estratégias provenientes da administração privada. Não por acaso, Sanfelice (2010, p. 147) afirma que tais governos conservaram em seus princípios uma clara inspiração político-ideológica razoavelmente comum. E nesta, como se nota, preservou-se a lógica de que política educacional se faz para a escola e não com a escola e de que a produtividade do ensino se sobrepõe a sua qualidade e as pessoas que a integram, na figura de alunos, gestores e professores. Como resultado desse modelo, segundo Ramos (2013, p. 551):

[...] ficou definido como papel central da escola [paulista] a busca por resultados de fluxo e de rendimento escolar, segundo parâmetros externos estabelecidos em índices (SARESP, IDESP, etc.). Ao professor, foi se fixando o papel de executor de tarefas previamente definidas para o alcance dos índices dos parâmetros externos, sendo regulado via capacitações doutrinárias com modelos pedagógicos variáveis, materiais didáticos estanques e avaliações de sistema, bem como "estimulado" por bonificações.

Desse modo, para o caso paulista, não seria exagero concordar com a tese de Freitas (2012), para quem as chamadas reformas empresariais da educação estão instaurando ou aprofundando nos sistemas de ensino processos como competição entre profissionais e escolas, pressão sobre o desempenho dos alunos, fraudes de resultados nas avaliações de sistema, estreitamento curricular e engessamento de material didático, precarização da formação do professor e sua consequente destruição moral, enfraquecendo cada vez mais as escolas, os sistemas de ensino e a possibilidade de construção de uma educação efetivamente de qualidade.

Sob esse contexto, pode-se dizer que a reeleição de Geraldo Alckmin para o governo do Estado paulista, no final de 2014, acena para permanência de tal modelo de gestão por ao menos mais quatro anos em São Paulo. Com isso, renova-se, neste momento, uma descrente esperança de que a qualidade do ensino se sobreponha à questão de sua quantidade e de que, para além dos números, seja efetivamente promovida a valorização dos seres humanos (alunos e profissionais da educação) pelo Estado paulista. 


\section{Racionality and managerialism in the São Paulo educational policy of 1995 to 2014: beyond conjunctures}

\section{Abstract}

This article presents a management model that supports the São Paulo's educational policy from 1995 to 2014, rebuilding the logic that underlies and intertwines the main programs, projects and activities implemented during the period. Based on a literature review and document analysis, it was found that, during this period, the organizational streamlining, changing patterns of management and quality of teaching improvement axes remained as the basis education reform. Under this setting, the analyzed material shows that this process is sustained by an education managerialist and rationing model and therefore the quality of teaching itself.

Keywords: São Paulo educational policy. Educational management. Quality of teaching.

\section{Racionalidad y gerencialismo en la política educativa de São Paulo desde 1995 hasta 2014: más allá de las coyunturas}

\section{Resumen}

En este artículo se presenta un modelo de gestión que apoya la política educativa de São Paulo desde 1995 hasta 2014, la reconstrucción, tanto para la lógica que subyace $y$ entrelaza los principales programas, proyectos y actividades realizadas durante el periodo. Sobre la base de la literatura y análisis de documentos, encontramos que en este periodo, los ejes, la racionalización de la organización, cambios en los patrones de gestión y mejora de la calidad de la enseñanza se han mantenido como el fundamento de la reforma de la educación en el estado. Bajo este escenario, el material analizado muestra que este proceso se sustenta en un modelo gerencial y el racionamiento de la educación y, por tanto, la calidad de la enseñanza en sí.

Palabras clave: Política educativa en São Paulo. Gestión de la educación. Calidad de la enseñanza. 


\section{Referências}

ABRAHÃO, R. C. R. A formação continuada de professores no Programa Teia do Saber - Universidade: um olhar avaliativo. 2006. $116 \mathrm{f}$.

Dissertação (Mestrado em Educação) - Pontifícia Universidade Católica de Campinas, Campinas.

ADRIÃO, T. Oferta do ensino fundamental em São Paulo: um novo modelo. Educação e Sociedade, Campinas, v. 29, n. 102, p. 79-98, jan./abr. 2008. doi:10.1590/S0101-73302008000100005

ADRIÃO, T.; GARCIA, T. Subsídio público ao setor privado: reflexões sobre a gestão da escola pública no Brasil. Políticas Educativas, Porto Alegre, v. 7, n. 2, p. 110-22, 2014.

ARCAS, P. H. Implicações da progressão continuada e do SARESP na avaliação escolar: tensões, dilemas e tendências. 2009. $178 \mathrm{f}$. Tese (Doutorado em Educação) - Universidade de São Paulo, São Paulo.

BARROS, M. C. M. M.; TAVARES, P. A.; MASSEI, W. O desenvolvimento da educação no Estado de São Paulo: sistema de avaliação do rendimento escolar, plano de desenvolvimento da educação e bonificação variável por desempenho. São Paulo em Perspectiva, São Paulo, v. 23, n. 1, p. 42-56, jan./jun. 2009.

BAUER, A. Usos dos resultados do SARESP: o papel da avaliação nas políticas de formação docente. 2006. 171 f. Dissertação (Mestrado em Educação) - Universidade de São Paulo, São Paulo.

BERGO, L. F. Escola de tempo integral: qual é o papel que se pretende para a escola? São Paulo: Fundação de Amparo à Pesquisa do Estado de São Paulo, 2014. (Relatório final de pesquisa).

BRASIL. Instituto Nacional de Estudos e Pesquisas Educacionais Anísio Teixeira - INEP. Saeb 2005: primeiros resultados: médias de desempenho do Saeb/2005 em perspectiva comparada. Brasília, DF, 2007. Disponível em: $<$ http://download.inep.gov.br/educacao_basica/prova_brasil_saeb/ resultados/SAEB1995_2005.pdf $>$. Acesso em: 5 ago. 2015.

- Instituto Nacional de Estudos e Pesquisas Educacionais Anísio Teixeira - INEP. Sipnoses estatísticas da educação básica: 1996. Brasília, DF, 1997. Disponível em: <http://portal.inep.gov.br/basica-censo-escolarsinopse-sinopse $>$. Acesso em: 4 dez. 2015. 
BRASIL. Instituto Nacional de Estudos e Pesquisas Educacionais Anísio Teixeira - INEP. Sipnoses estatísticas da educação básica: 2001. Brasília, 2002. Disponível em: $<$ http://portal.inep.gov.br/basica-censo-escolar-sinopsesinopse>. Acesso em: 4 dez. 2015.

. Presidência da República. Câmara da Reforma do Estado. Plano diretor da reforma do aparelho do Estado. Brasília, DF, 1995.

. Presidente. Palavra do presidente - Fernando Henrique Cardoso.

Brasília, DF; Presidência da República, 2002. v. 2.

BRESSER-PEREIRA, L. C. Da administração pública burocrática à gerencial. Revista do Servidor Público, Brasília, DF, v. 120, n. 1, p. 9-44, jan./abr. 1996.

CANCIAN, N. SP convoca, pela quarta vez, docentes reprovados em teste. Folha de São Paulo, 2 mar 2013. Disponível em: <http://www.apeoesp.org.br/ noticias/noticias/sp-convoca-pela-quarta-vez-docentes-reprovados-em-teste/ $>$. Acesso: 3 nov. 2014.

CATANZARO, F. O. O programa São Paulo faz escola e suas apropriações no cotidiano de uma escola de Ensino Médio. 2012. 126 f. Dissertação (Mestrado em Educação) - Universidade de São Paulo, São Paulo.

CONSTANCIO, A. R. A padronização do trabalho docente: crítica do Programa Ler e Escrever. 2012. 130 f. Dissertação (Mestrado em Educação) - Pontifícia Universidade Católica de São Paulo, São Paulo.

COSTA, F. L. Reforma do Estado e contexto brasileiro: crítica ao paradigma gerencialista. Rio de Janeiro: Editora FGV, 2010.

DUARTE, N. Vigotski e o "aprender a aprender": crítica às apropriações neoliberais e pós-modernas da teoria vigotskiana. Campinas: Autores Associados, 2000.

. As pedagogias do "aprender a aprender" e algumas ilusões da assim chamada sociedade do conhecimento. Revista Brasileira de Educação, Rio de Janeiro, n. 18, p. 35-40, set./dez. 2001. doi:10.1590/S1413-24782001000300004

ESTADO DE SÃO PAULO. A reinvenção da escola. 22 ago. 2007. Editorial.

FIAMENGUI, G. Impactos do Projeto São Paulo Faz Escola no trabalho do professor. 2008. 134 f. Dissertação (Mestrado em Educação) - Universidade Católica de Santos, Santos. 
FOLHA DE SÃO PAULO. Secretária de Covas faz críticas ao secretário de Alckmin. São Paulo, 12 mar. 2007. Cotidiano.

FREITAS, L. C. Os reformadores empresariais da educação: da desmoralização do magistério à destruição do sistema público de educação. Educação e Sociedade, Campinas, v. 33, n. 119, p. 379-404, abr.jun. 2012. doi:10.1590/S0101-73302012000200004

GRAMSCI, A. Maquiavel, a política e o estado moderno. Rio de Janeiro: Civilização Brasileira, 1968.

JUNQUILHO, G. S. Teorias da administração pública. Florianópolis: UFSC; Brasília, DF: UAB, 2010.

LIBANORI, G. A. A família vai à escola: um estudo das concepções de justiça social, cidadania e parcerias comunitárias em cinco programas da secretaria de Estado da educação de São Paulo. 2011. 187 f. Dissertação (Mestrado em Educação) - Universidade Federal de São Carlos, São Carlos.

LOUREIRO. B. R. C. Reforma educacional neoliberal: uma análise política da concessão de Bônus-Mérito do governo José Serra (2007-2010) aos professores da rede estadual paulista. 2011. 130 f. Dissertação (Mestrado em Ciências Sociais) - Universidade Estadual Paulista, Marília.

MARQUES, L.M. Programa de Valorização pelo Mérito implantado pela Secretaria do Estado da Educação de São Paulo: opiniões de professores coordenadores. 2012. 137 f. Dissertação (Mestrado em Educação) - Universidade Cidade de São Paulo, São Paulo.

MARSIGLIA, A. C. G. Um quarto de século de construtivismo como discurso pedagógico oficial na rede estadual de ensino paulista: análise de programas e documentos da secretaria de Estado da educação no período de 1983 a 2008. 2011. 227 f. Tese (Doutorado em Educação) - Universidade Estadual Paulista, Araraquara.

MARTINS, M. A. O público não-estatal na gestão da educação básica de Barcarena/ PA. 2010. 191 f. Dissertação (Mestrado em Educação) - Universidade Federal do Pará, Belém.

NEUBAUER, R. Descentralização da educação no Estado de São Paulo. In. COSTA, V. L. C. (Org.). Descentralização da educação: novas formas de coordenação e financiamento. São Paulo: Fundap, Cortez, 1999. p. 168-97. 
NOVAES, L. C. Os impactos da política educacional paulista na prática docente e na organização do trabalho pedagógico nas escolas estaduais paulistas na perspectiva dos professores. Jornal de Políticas Educacionais, Curitiba, v. 3, n. 5, p. 13-22, jan./jun. 2009. doi:10.5380/jpe.v3i5.17349

PAES, M. V. O professor no programa São Paulo faz escola: afinal, quem faz a escola? São Paulo: Fundação de Amparo à Pesquisa do Estado de São Paulo, 2012. (Relatório final de pesquisa).

PALMA FILHO, J. C. A Política Educacional do Estado de São Paulo (1983-2008). In: CONGRESSO ESTADUAL PAULISTA SOBRE FORMAÇÃO DE EDUCADORES, 10., 2009, Águas de Lindóia. Anais... São Paulo: Fundação UNESP, 2009. p. 6053-65.

PAULA, A. R. Proposta curricular do Estado de São Paulo: novos papéis ou continuísmo na prática escolar do professor coordenador? 2012. $245 \mathrm{f}$. Tese (Doutorado em Educação) - Universidade Federal de São Carlos, São Carlos.

PUCCI, L. F. S. A proposta da escola de tempo integral no Estado de São Paulo: novos desafios para a escola pública e para a formação de professores. Cadernos de Pós-Graduação, São Paulo, v. 4, p. 75-83, 2005.

RAMOS, G. P. Entre a proposta e o pretexto da qualidade do ensino: uma leitura sobre os liames da valorização docente a partir do FUNDEF. 2008. 310 f. Tese (Doutorado em Educação) - Universidade Federal de São Carlos, São Carlos.

RAMOS, G. P. O professor na política educacional: tentativa de identidades forjadas? Revista Brasileira de Política e Administração da Educação, v. 28, n.1, p. 129-43, jan/abr. 2012.

RAMOS, G. P. A política educacional paulista (1995-2010) e seus impactos na identidade da escola e do professor. Revista Brasileira de Política e Administração da Educação, v. 29, n.3, p. 537-56, set./dez. 2013.

RIBEIRO, M. E. S.; CHAVES, V. L. J. Gestão educacional: modelos e práticas. In: ENCONTRO IBEROAMERICANO EM EDUCAÇÃO, 6., 2012, Chile, Santiago. Anais... Chile: Universidad Metropolitana de la Ciencias de la Educacion, 2012. v. 1. p. 1-15.

SANFELICE, J. L. A política educacional no Estado de São Paulo: apontamentos. Nuances: Estudos sobre Educação, v. 17, n. 18, p. 146-59, jan./dez. 2010 
SÃO PAULO (Estado). Assembléia Legislativa do Estado de São Paulo. Agência de Notícias. Cesar Callegari critica a política educacional do Estado no Dia do Professor. 15 out. 2001 Disponível em: <http://www.al.sp.gov.br/ noticia/?id=273926> . Acesso em: 10 mar. 2014.

. Decreto ${ }^{\circ} 52.719$, de 14 de fevereiro de 2008a. Regulamenta e define critérios para concessão do bônus aos integrantes do Quadro do Magistério e dá providências correlatas. Diário Oficial do Estado, São Paulo, SP, Seção I, p. 1, 15 ago 2008a.

. Decreto $\mathrm{n}^{\circ} 57.571$, de 2 de dezembro de 2011. Institui, junto à Secretaria da Educação, o Programa Educação - Compromisso de São Paulo e dá providências correlatas. Diário Oficial do Estado, São Paulo, Seção 1, p. 14, 3 dez 2011.

. Lei Complementar $n^{\circ} 1.078 / 08$, de 17 de dezembro de 2008b. Institui Bonificação por Resultados - BR, no âmbito da Secretaria da Educação, e dá providências correlatas. Diário Oficial do Estado, São Paulo, Seção 1, p. 1, 18 dez 2008b.

. Portal do Governo. SP Notícias. Veja as 10 metas do novo Plano Estadual de Educação. São Paulo, 20 ago 2007. Disponível em: $<$ http://www.saopaulo.sp.gov.br/spnoticias/lenoticia.php?id=87027>. Acesso em: 18 maio 2014.

. Secretaria da Educação. Fundação para o Desenvolvimento da Educação de Qualidade - FDE. Escola em parceria. São Paulo: FDE, 2013a.

. Secretaria de Estado da Educação. A nova estrutura administrativa da Secretaria da Educação do Estado de São Paulo: por uma gestão de resultado com foco no desempenho do aluno. São Paulo, 2013b.

. Secretaria de Estado da Educação. Comunicado SE, de 22 de março de 1995. Torna público a todos os integrantes dos Quadros do Magistério, de Apoio Escolar e da Secretaria da Educação, as principais diretrizes educacionais para o Estado de São Paulo, para o período de janeiro de 1995 a 31 de dezembro de 1998. Diário Oficial do Estado, São Paulo, Seção 1, p. 8-10, 23 mar 1995.

. Secretaria de Estado da Educação. Descentralização e reformas do Ensino Fundamental: unindo forças para construir, com sucesso, uma escola de cara nova para São Paulo. São Paulo, 1997. 
SÃO PAULO (Estado). Secretaria de Estado da Educação. Política Educacional da Secretaria de Estado da Educação de São Paulo. São Paulo, 2003. Disponível em: <http://www.crmariocovas.sp.gov.br/pdf/ors/ PoliticaSEE.pdf $>$. Acesso em: $20 \mathrm{dez} .2013$.

SILVA, J. C. A política educacional do governo Serra (2007-20010): uma análise da atuação da APEOESP. 2013. 220 f. Dissertação (Mestrado em Educação) - Universidade Estadual de Campinas, São Paulo.

SOUZA, A. N. A racionalidade econômica na política educacional em São Paulo. Pro-posições, Campinas, v. 13, n. 1, p. 105-30, 2002.

SOUZA FILHO, R. Crítica à concepção gerencialista de gestão pública: o caso Brasileiro. In: SEMINÁRIO LATINOAMERICANO DE ESCUELAS DE TRABAJO SOCIAL, 19., 2009, Guayaquil. Anais... Guayaquil, 2009. p. 1-11. Disponível em: $<$ http://www.ts.ucr.ac.cr/binarios/congresos/reg/slets/ slets-019-166.pdf >. Acesso em: 10 mar. 2014.

TERTO, D. C.; PEREIRA, R. L. A. A Nova Gestão Pública e as atuais tendências da gestão educacional. In: SIMPÓSIO BRASILEIRO, 25.; CONGRESSO IBERO-AMERICANO DE POLÍTICA E ADMINISTRAÇÃO DA EDUCAÇÃO, 2., 2011, São Paulo. Anais... São Paulo: ANPAE, 2011. p. 1-10. Disponível em: $<$ http://www.anpae.org.br/simposio2011/cdrom2011/PDFs/ trabalhosCompletos/posters/0041.pdf > . Acesso em: 10 mar. 2014.

VIEIRA, N. P. Indo mais rápido: para onde? Um estudo do Projeto Classes de Aceleração da Secretaria de Estado da Educação de São Paulo. 2002. 116 f. Dissertação (Mestrado em Educação) - Universidade de São Paulo, São Paulo.

VIRIATO, E. A política educacional do Estado de São Paulo (1995-1998): desconstrução da escola pública. 2001. 199 f. Tese (Doutorado em Educação) - Pontifícia Universidade Católica de São Paulo, São Paulo.

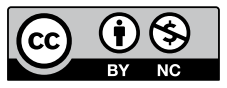

\section{Informações da autora}

Géssica Priscila Ramos: Doutorado em Educação pela Universidade Federal de São Carlos - UFSCar. Professora Adjunta da Universidade Federal de São Carlos - UFSCar. Contato: gessicaramos@ufscar.br 